\title{
Changes in the sea-ice brine community during the spring-summer transition, McMurdo Sound, Antarctica. II. Phagotrophic protists
}

\author{
Diane K. Stoecker ${ }^{1}$, Kurt R. Buck ${ }^{2}$, Mary Putt ${ }^{3}$ \\ ${ }^{1}$ Horn Point Environmental Laboratory, PO Box 775, Cambridge, Maryland 21613, USA \\ ${ }^{2}$ Monterey Bay Aquarium Research Institute, 160 Central Avenue, Pacific Grove, California 93950, USA \\ ${ }^{3}$ Department of Oceanography, Old Dominion University, Norfolk, Virginia 23529, USA
}

\begin{abstract}
The land-fast sea-ice brine contains a diverse phagotrophic protist assemblage consisting of $<5 \mu \mathrm{m}$ heterotrophic flagellates, Cryothecomonas spp., heterotrophic dinoflagellates, and heterotrophic and mixotrophic ciliates. Fine-scale horizontal spatial variability is a feature of this assemblage; samples taken within $1 \mathrm{~m}$ of each other can be dominated by different heterotrophic protists. Many of the larger heterotrophic protists found in the brine are also found in the water column. The photosynthetic ciliate Mesodinium rubrum is also common. In mid to late austral spring, the heterotrophic assemblage accounts for ca $10 \%$ of the total protist biomass in the brine and is dominated by Cryothecomonas spp. This flagellate can reach densities of over $10^{6}$ cells $1^{-1}$ of brine. In the early austral summer, ciliates (primarily Strombidium spp., Mesodinium rubrum and Didinium spp.) and heterotrophic dinoflagellates (primarily a small Gymnodinium $\mathrm{sp}$. and Polykrikos sp.) increase in abundance in the brine. Ciliate densities of $\geq 3 \times 10^{3} 1^{-1}$ and heterotrophic dinoflagellate densities of $10^{4}$ cells $1^{-1}$ are common in the brine during early summer. By the end of January (just prior to ice decay and break-out), heterotrophic flagellates and ciliates can account for $50 \%$ of the protist biomass.
\end{abstract}

\section{INTRODUCTION}

Sea-ice is a dominant feature of polar seas; it annually covers a maximum of ca $20 \times 10^{6} \mathrm{~km}^{2}$ in the southern hemisphere (Zwally et al. 1983) and ca $14 \times$ $10^{6} \mathrm{~km}^{2}$ in the northern hemisphere (Comiso 1986). Sea-ice plays an important role in determining energy balance and ocean-atmosphere interactions on a global scale (reviewed in Eicken 1992, Legendre et al. 1992). It is a major habitat for marine biota in polar environments (Garrison et al. 1986, Horner et al. 1992) and is important in structuring polar marine ecosystems (Eicken 1992).

The sea-ice microbial community is important in several respects. Production by sea-ice protists can make a significant contribution to food webs in the plankton and in the benthos (Knox 1990, Matsuda et al. 1990, Bianchi et al. 1992, Lizotte \& Sullivan 1992). Furthermore, the presence and growth of protists in surface and interior habitats in sea-ice is thought to: (1) increase light attenuation in the sea-ice and alter the spectral quality of light reaching the base of the sea-ice and the underlying water column (SooHoo et al. 1987, Arrigo et al. 1991), and (2) increase heat absorption and thus influence the physical structure of sea-ice and its break-up (Meguro 1962, Buynitskiy 1968, McConville \& Wetherbee 1983, Maykut 1985. Eicken et al. 1991, Stoecker et al. 1992).

In polar environments 2 types of sea-ice occur. Landfast sea-ice forms and remains fast along the coast, the rest is pack-ice (Horner et al. 1992). In general, the 2 types differ in their mode of formation, physical structure and biota (reviewed in Garrison et al. 1986, Horner et al. 1992). In land-fast ice, protist communities are often most conspicuous at or near the bottom of the sea-ice and are diatom-dominated (Hoshiai 1972, McConville \& Wetherbee 1983, Palmisano \& Sullivan 1983, Sasaki \& Watanabe 1984). In pack-ice, subsurface brine and interior algal assemblages are most common (Ackley et al. 1979, Garrison \& Buck 1989 , 1991, Spindler et al. 1990). Pack-ice communities are often dominated by diatoms, but also contain a diverse 
assemblage of other autotrophs and phagotrophic protists (Garrison \& Buck 1989, Spindler et al. 1990).

Recently we reported a flagellate-dominated brine assemblage from the upper land-fast ice in McMurdo Sound, Antarctica (Stoecker et al. 1990, 1991, 1992). During late December and early January, the autotrophic assemblage in the brine peaks, with biomass reaching $\geq 100 \mu \mathrm{g} \mathrm{l}^{-1}$ and chlorophyll $a \geq 3 \mu \mathrm{g} \mathrm{l}^{-1}$ (Stoecker et al. 1992). This assemblage is distinct from the diatom-dominated assemblages at the base of the sea-ice. The dominant photosynthetic protists in the upper land-fast brine are a small non-thecate dinoflagellate, a prasinomonad (Mantoniella sp.), and unidentified chrysophyte statocysts (Stoecker et al. 1992); these taxa are also common in pack-ice (Garrison \& Buck 1989).

Although hetrotrophic protists are often the major consumers of primary production and the primary agents of nutrient regeneration in aquatic environments (reviewed in Capriulo et al. 1991, Caron 1991), almost nothing was known about their ecology in landfast sea-ice. Algal and bacterial assemblages have been studied in land-fast sea-ice (Kottmeier \& Sullivan 1988), but the heterotrophic protists in this habitat have largely been ignored. Preliminary studies in 1989-90 revealed that ciliates were present in the upper land-fast sea-ice brine community in McMurdo Sound (Stoecker et al. 1990).

In pack-ice surface brine assemblages, heterotrophic protists can comprise from 1 to $>93 \%$ of the protist biomass; it has been hypothesized that grazing by protists influences algal growth and biomass accumulation (Garrison \& Buck 1991). Studies in pack-ice indicate that an active microbial food web functions within seaice, but time series data on the population dynamics of autotrophic and heterotrophic components of the community were not available (Garrison \& Buck 1989). The occurrence of very high ammonia concentrations in some samples of both land-fast and pack-ice suggest that the activities of heterotrophic protists may have an important influence on biological and chemical parameters in sea-ice (Arrigo et al. 1990, Dieckmann et al. 1991).

Here we report on the heterotrophic and mixotrophic components of the protist assemblage in the upper land-fast in McMurdo Sound during the springsummer transition. Access to the land-fast ice at McMurdo allows repeated observation of the upper sea-ice brine community, and thus seasonal trends can be investigated. Because the upper land-fast ice brine assemblage has many properties in common with the more complex and more difficult to sample pack-ice assemblage, it may be an excellent model system in which to observe processes common to both land-fast and pack-ice communities (Stoecker et al. 1992).

\section{METHODS}

Samples were collected by drilling holes approximately $50 \mathrm{~cm}$ into the land-fast, annual sea-ice in McMurdo Sound, Antarctica (Fig. 1). Brine was allowed to accumulate in the holes, and the accumulated brine was collected by gently pumping it with a hand vacuum pump into a polycarbonate bottle wrapped with duct tape to keep the contents from being exposed to light (Stoecker et al. 1992). During the 1990-91 field season, 11 sites 25 to $50 \mathrm{~m}$ from the retreating ice edge were sampled between 15 December and 31 January. Sampling at the ice edge sites was biased by the fact that we only sampled sites where the sea-ice was suitable for a helicopter to land. Since the ice edge was retreating and thus constantly changing in position, each site was only sampled once. During our field season, the ice edge on the eastern side of the sound retreated from north of Cape Byrd to Cape Royds; the area in which we sampled this retreating edge is shown in Fig. 1. For most sites/dates, between 2 and 4 replicate sampling holes were drilled at $1 \mathrm{~m}$ intervals along a short transect on the ice.

For comparison with the ice edge sites and to allow for repeated sampling at 1 site, a fixed location (H90) on the annual land-fast sea-ice near McMurdo Station was chosen for sampling (Fig. 1). Contrary to our expectations, the sea-ice at $\mathrm{H} 90$ decayed faster than at some more northern locations in McMurdo Sound, and after early January 1991, it was not possible to access this site. Triplicate brine samples, spaced at $1 \mathrm{~m}$ intervals, were taken on 3 dates between 30 November and 5 January at $\mathrm{H} 90$.

At both the ice edge and H90 sites, brine temperature was determined by immersing a thermometer in the brine which had accumulated in the holes. Brine samples stored in insulated containers were taken to the laboratory within a few hours of collection where samples were fixed for later microscopic enumeration. Salinity was determined in the laboratory with a refractometer. Triplicate subsamples were extracted in $90 \%$ acetone and the chlorophyll a content determined by fluorometry (Parsons et al. 1984).

For enumeration and sizing of $<20 \mu \mathrm{m}$ protists, 5 to $20 \mathrm{ml}$ subsamples were preserved with glutaraldehyde (final conc. $0.3 \%$ ), stained with proflavine (final conc. $0.5 \mu \mathrm{g} \mathrm{ml}^{-1}$ ) and collected on $1.0 \mu \mathrm{m}$ pore size polycarbonate filters and examined using epifluorescent microscopy (BP 450 to $490 \mathrm{~nm}$ excitation filter, FT 510 chromatic beam splitter, Lp $520 \mathrm{~nm}$ barrier filter). With this technique, cells can be categorized as plastidic or non-plastidic based on their fluorescence patterns (Haas 1982). Protists $>20 \mu \mathrm{m}$ in size were preserved either in 5\% acid Lugol's solution or 5\% (final conc.) buffered formalin, 50 or $100 \mathrm{ml}$ samples were settled 


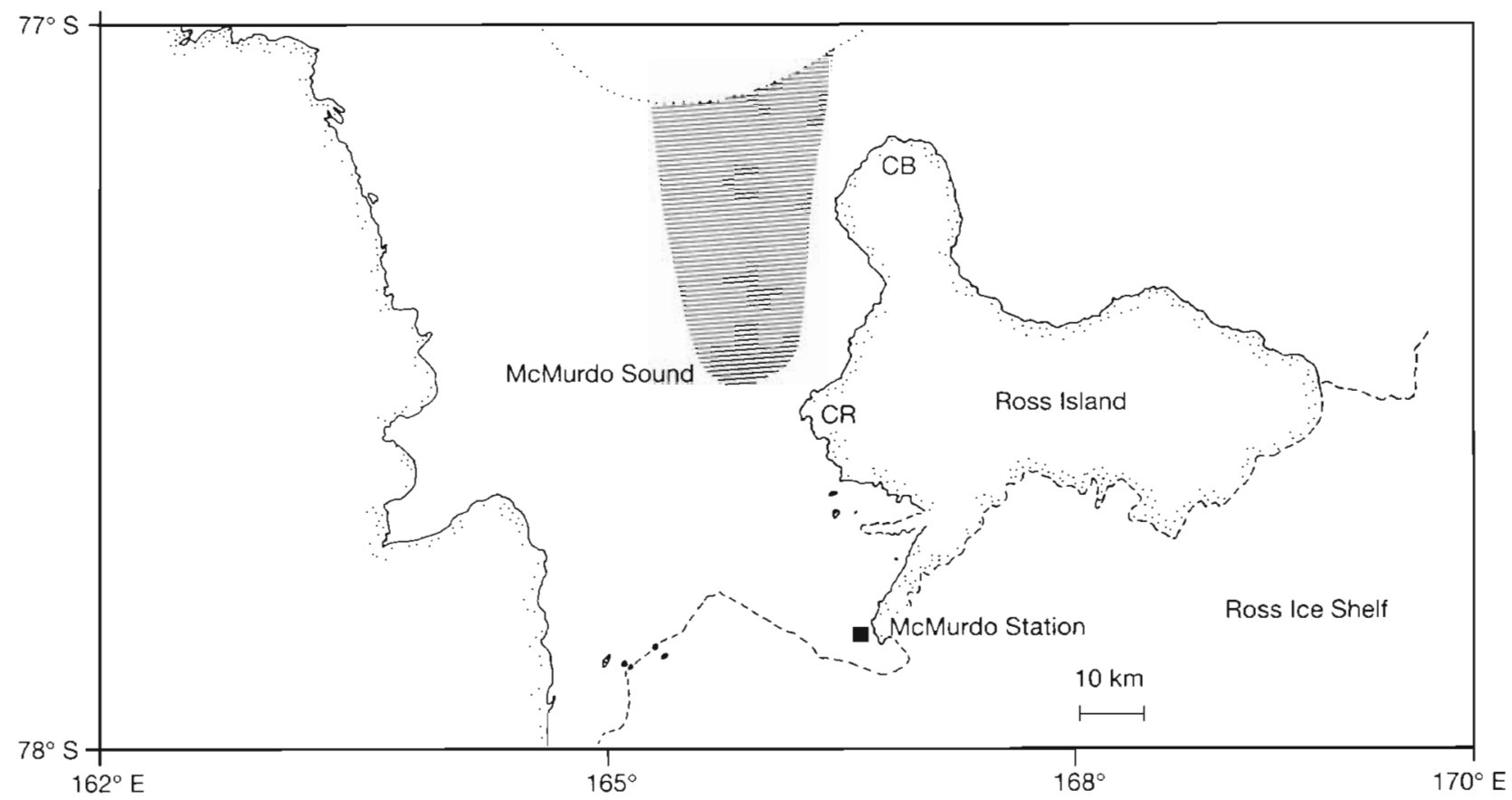

Fig. 1. Sampling locations on the annual land-fast sea-ice in McMurdo Sound, Antarctica, 1990-91. During the sampling season, the ice edge was retreating and hence constantly changing. $(\cdots . .$.$) Approximate location of the ice edge at the beginning of our$ sampling season in early December; (...-) the margin between the annual land-fast sea-ice and the Ross Ice Shelf. Shading indicates location of ice edge sites on the east side of MCMurdo Sound. During our sampling season, the ice edge within this area retreated from the north of Cape Byrd $(C B)$ to the vicinity of Cape Royds (CR). Ice edge land-fast ice sampling sites were approximately 25 to $50 \mathrm{~m}$ to the south of the retreating edge (precise locations are not known). ( $\boldsymbol{\square}$ ) H90, located near McMurdo Station on the land-fast ice. At the times this site was sampled, the ice edge was north of Cape Royds

and examined using transmitted and epifluorescence microscopy (Stoecker et al. 1992). Sizing of $>20 \mu \mathrm{m}$ protists was based on specimens preserved with formalin. Cell sizes were measured with an ocular micrometer and converted to cell volumes using appropriate geometric formulae. The same conversion factor used for the microalgae (Stoecker et al. 1992), 0.14 pg C $\mu \mathrm{m}^{-3}$, was used to convert protozoan biovolumes to biomass. This factor has been suggested for heterotrophic dinoflagellates fixed with glutaldehyde (Lessard 1991) and for ciliates fixed with $5 \%$ formalin (Putt \& Stoecker 1989).

Microscopic analyses revealed that samples taken from replicate holes drilled $1 \mathrm{~m}$ apart at a site often differed considerably in the abundance and species composition of the phagotrophic protist assemblage. Variability among 'replicate' samples could be due either to counting errors or to fine-scale horizontal variability (differences among holes at a site). In order to evaluate these possibilities, samples were taken from 3 replicate holes spaced approximately $1 \mathrm{~m}$ apart and 3 replicate subsamples from each sample (i.e. hole) were analyzed microscopically. A random effects (Model II) 1 -way analyses of variance was used to estimate the components of the variance associated with small scale horizontal variability and counting error (Meyers \& Milton 1991).

For scanning electron microscopy (SEM), samples were preserved in 10\% Bouin's solution and settled on polylysine coated coverslips. Samples were then postfixed in osmium tetroxide, serially dehydrated in acetone in $10 \%$ steps and critically point dried (Thomsen et al. 1991).

\section{RESULTS}

\section{Physical and chemical parameters}

At the ice edge sites, brine temperature ranged between -1.85 and $-0.3^{\circ} \mathrm{C}$, brine salinity ranged between 0 and 36 psu (practical salinity units) and chlorophyll a content varied between 0.1 and $3.8 \mu \mathrm{g} \mathrm{l}^{-1}$ of brine (Table 1). Contrary to expectations, at H90 the land-fast ice decayed faster than at some more northern locations in McMurdo Sound. By early January, the sea-ice at H90 had become very porous (Stoecker et al. 1992), the brine temperature had risen to between -0.2 and $0{ }^{\circ} \mathrm{C}$, and the brine salinity had decreased to $\leq 2$ psu (Table 2 ). 
Table 1. Mean densities (SD) of phagotrophic protists in the upper sea-ice brine, ice edge sites, McMurdo Sound, $1990-91$. On each sampling date 2 to 4 samples were obtained ca $1 \mathrm{~m}$ apart at each site. The mean for each time period was calculated from the means for each date/site

\begin{tabular}{|c|c|c|c|c|}
\hline & Dimensions $(\mu \mathrm{m})$ & 15-31 Dec & $1-15 \operatorname{Jan}$ & 16-31 Jan \\
\hline No. of sampling dates & & 4 & 4 & 3 \\
\hline Avg. no. of samples date ${ }^{-1}$ & & 2.7 & 3.5 & 2.3 \\
\hline Brine temperature $\left({ }^{\circ} \mathrm{C}\right)$ & & -1.85 to -0.3 & -0.9 to -0.3 & -1.5 to -0.5 \\
\hline Brine salinity (psu) & & 9 to 36 & 12 to 29 & 19 to 25 \\
\hline $\mathrm{Chl} a\left(\mu \mathrm{gl}^{-1}\right)$ & & 0.2 to 3.8 & 0.1 to 0.9 & 0.1 to 0.9 \\
\hline \multicolumn{5}{|l|}{ Phagotrophic protists (cells $1^{-1}$ ) } \\
\hline \multicolumn{5}{|l|}{ Flagellates } \\
\hline $\begin{array}{l}\text { Unident. heterotrophic flag. } \leq 5 \mu \mathrm{m} \\
\text { Cryothecomas }\end{array}$ & 2 to 4 & $3.2 \times 10^{5}\left(1.8 \times 10^{5}\right)$ & $1.9 \times 10^{5}\left(2.3 \times 10^{5}\right)$ & $0.8 \times 10^{5}\left(0.9 \times 10^{5}\right)$ \\
\hline C. armigera & $7 \times 14$ & $2.3 \times 10^{4}\left(2.6 \times 10^{4}\right)$ & $5.4 \times 10^{4}\left(9.3 \times 10^{4}\right)$ & $<50$ \\
\hline Cryothecomas sp. & $5 \times 7$ & $1.3 \times 10^{6}\left(2.2 \times 10^{6}\right)$ & $1.0 \times 10^{6}\left(1.7 \times 10^{6}\right)$ & $<50$ \\
\hline \multicolumn{5}{|l|}{ Heterotrophic dinoflagellates } \\
\hline Gymnodinium sp. & $10 \times 17$ & $0.3 \times 10^{4}\left(0.5 \times 10^{4}\right)$ & $2.2 \times 10^{4}\left(2.8 \times 10^{4}\right)$ & $1.9 \times 10^{4}\left(1.2 \times 10^{4}\right)$ \\
\hline Polykrikos sp & $34 \times 121$ & $45(52)$ & $114(37)$ & $35(50)$ \\
\hline Gyrodinium sp. & $34 \times 129$ & $2(5)$ & $22(28)$ & $19(12)$ \\
\hline Protoperidinium sp. & 35 to 40 & $<10$ & $15(26)$ & $<10$ \\
\hline Ciliates (total) ${ }^{\mathrm{a}}$ & & $1.2 \times 10^{3}\left(0.7 \times 10^{3}\right)$ & $4.8 \times 10^{3}\left(3.8 \times 10^{3}\right)$ & $3.6 \times 10^{3}\left(2.2 \times 10^{3}\right)$ \\
\hline Oligotrichs (total) & & $0.7 \times 10^{3}\left(0.5 \times 10^{3}\right)$ & $2.9 \times 10^{3}\left(2.0 \times 10^{3}\right)$ & $2.1 \times 10^{3}\left(0.4 \times 10^{3}\right)$ \\
\hline \multicolumn{5}{|l|}{ Selected species } \\
\hline Strombidium sp. $2^{\mathrm{b}}$ & $25 \times 30$ & $46(80)$ & $71(126)$ & $471(816)$ \\
\hline Strombidium sp. 3 & $20 \times 25$ & $110(207)$ & $185(232)$ & $72(119)$ \\
\hline Strombidium sp. 4 & $45 \times 60$ & $204(317)$ & $1100(700)$ & $751(1100)$ \\
\hline Strombidium sp. $6^{\text {b }}$ & 30 & $136(220)$ & $<10$ & $387(671)$ \\
\hline Strombidium sp. $9^{\mathrm{b}}$ & $30 \times 60$ & $24(48)$ & $909(1557)$ & $243(328)$ \\
\hline Strombidium sp. 14 & 15 to 20 & $25(50)$ & $264(404)$ & $19(16)$ \\
\hline Mesodinium rubrum ${ }^{\mathrm{b}}$ & 20 to 30 & $156(151)$ & $1830(1779)$ & $728(852)$ \\
\hline Didinium spp. & 25 to 60 & $<10$ & $<10$ & $740(1000)$ \\
\hline Scuticociliate sp. & $10 \times 25$ & $340(630)$ & $<10$ & $7(12)$ \\
\hline
\end{tabular}

\section{Composition and abundance of heterotrophic flagellates and ciliates}

The phagotrophic protist assemblage of the upper land-fast ice brine community consisted of unidentified $<5 \mathrm{~mm}$ heterotrophic flagellates, flagellates in the genus Cryothecomonas, heterotrophic dinoflagellates and ciliates (Tables $1 \& 2$, Fig. 2). The $<5 \mu$ m category was comprised of heterotrophic cells about $2 \times 4 \mu \mathrm{m}$ in size; these generally occurred at densities of $10^{4}$ to $10^{5}$ cells $1^{-1}$ and made up $<3 \%$ of the heterotrophic protist biomass (Figs. $3 \& 4$ ).

Two species of Cryothecomonas, C. armigera Thomsen \& Buck 1991 and an unidentified 5 to $7 \mu \mathrm{m}$ species were present in the brine at some sites (Fig. 2). During late December and early January, the average density of $C$. armigera at the ice edge sites was high, $10^{4}$ to $10^{5}$ cells $1^{-1}$, but it decreased to $<50$ cells $l^{-1}$ by late January (Table 1). The temporal pattern of abundance of Cryothecomonas spp. at H90 was similar, except that the peak and drop in abundance occurred earlier than at the ice edge sites (Table 2). Cells of Mantoniella sp. were observed within the food vacuoles of $C$. armigera. The smaller, unidentified Cryothecomonas sp. occurred at average densities of $10^{6}$ cells $1^{-1}$ in the samples collected near the ice edge during late December and early January (Table 1); it was not observed in the H90 samples. Although Cryothecomonas spp. occurred sporadically in samples (Tables $3 \& 4$ ), this genus contributed on average over $50 \%$ of the biomass of heterotrophic protists in the ice edge brine samples during the last half of December and in the H90 samples taken in late November (Figs. $3 \& 4$ ). Near the end of the sampling period, the contribution of Cryothecomonas to biomass in the brine was negligible (Figs. $3 \& 4$ ).

Heterotrophic dinoflagellates were a common component of the protist assemblage (Tables $1 \& 2$ ). On average, this group contributed 5 to $15 \%$ of the biomass of heterotrophic protists in the brine samples collected near the ice edge (Fig. 3). The dominant species 


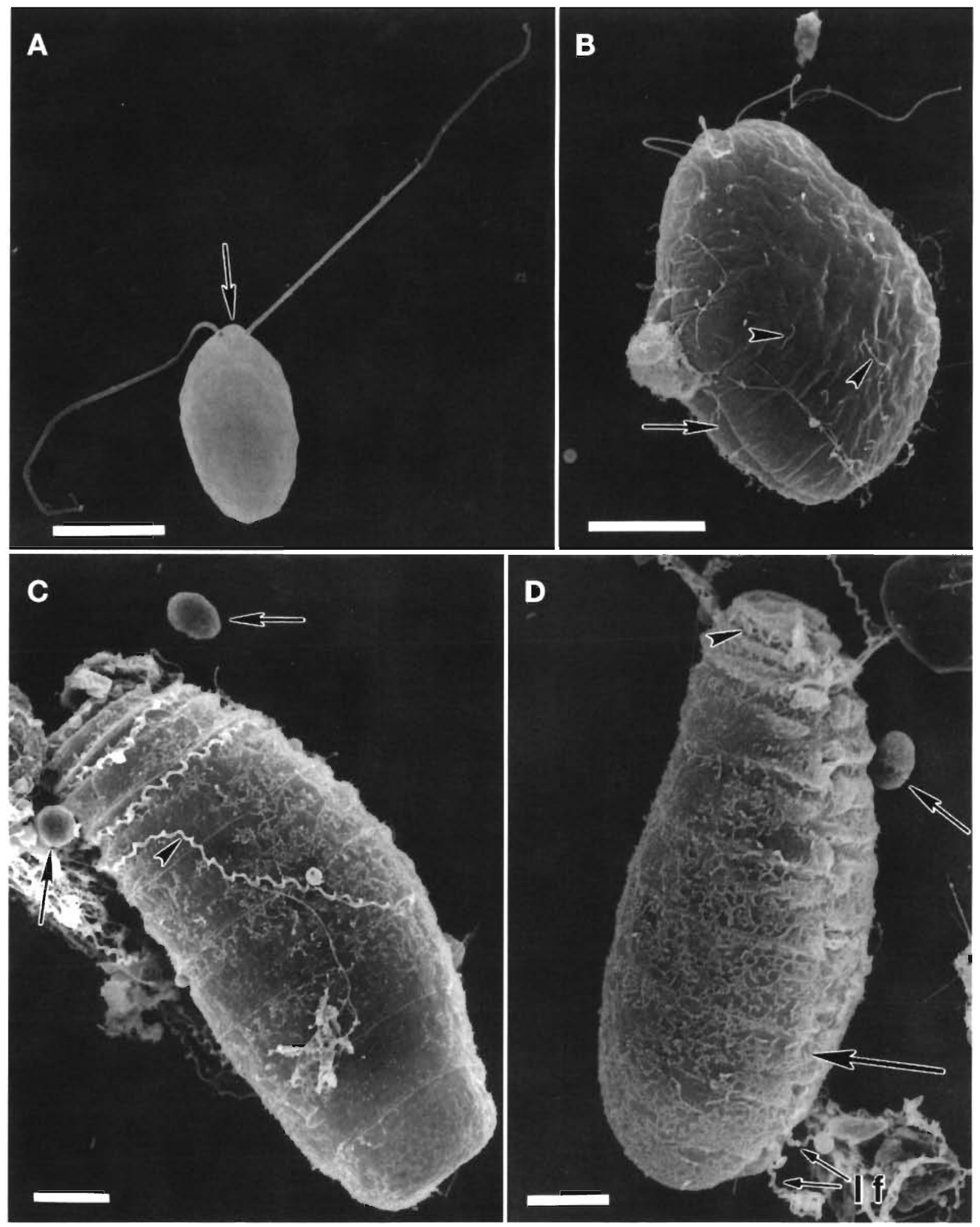

Fig. 2. Scanning electron micrographs. (A) Small Cryothecomonas sp. with 2 slightly unequal apically inserted flagella arising from either side of a papilla (arrow). Scale bar $=5 \mu \mathrm{m}$. (B) C. armigera with 2 apically inserted flagella, cytostomal slit (arrow) and discharged extrusomes (arrowheads). Scale bar $=10 \mu \mathrm{m}$. (C) Polykrikos sp. with cingulum and transverse flagellum. Small vegetative form of the dominant autotrophic dinoflagellate (arrows) that is a major component of the brine and which is preyed on by Polykrikos sp. Scale bar $=10 \mu \mathrm{m}$. (D) Polykrikos sp. showing cingulum with transverse flagellum (arrowhead), sulcus (large arrow) and longitundal flagella (lf). Stage had to be tilted $30^{\circ}$ to obtain this picture of the sulcus. Small vegetative form of the dominant autotrophic dinoflagellate is indicated by a small arrow. Scale bar $=10 \mu \mathrm{m}$ 
Table 2. Changes (means and SD) in phagotrophic protist densities in the upper sea-ice brine, H90, McMurdo Sound, 1990-91. ND: no data

\begin{tabular}{|c|c|c|c|c|}
\hline & 30 Nov & $12 \mathrm{Dec}$ & $24 \mathrm{Dec}$ & $5 \mathrm{Jan}$ \\
\hline Brine temp. $\left({ }^{\circ} \mathrm{C}\right)^{a}$ & -2.0 & -1.0 to -1.3 & -0.7 to -0.2 & -0.2 to 0.0 \\
\hline Brine salinity (psu) ${ }^{a}$ & 51 to 52 & 31 to 42 & 3 to 31 & $<1$ to 2 \\
\hline Chl $2\left(\mu \mathrm{gl}^{-1}\right)^{\mathrm{a}}$ & 0.32 to 1.14 & 1.2 to 3.9 & 0.3 to 0.8 & 0.3 to 0.5 \\
\hline \multicolumn{5}{|l|}{ Protists (cells $\left.\mathrm{l}^{-1}\right)^{\mathrm{b}}$} \\
\hline \multicolumn{5}{|l|}{ Flagellates } \\
\hline $\begin{array}{l}\text { Unidentified heterotrophic } \\
\text { flagellates } \leq 5 \mu \mathrm{m}\end{array}$ & ND & $5.7 \times 10^{4}\left(6.4 \times 10^{4}\right)$ & $2.0 \times 10^{4}\left(3.1 \times 10^{4}\right)$ & $1.4 \times 10^{4}\left(2.0 \times 10^{4}\right)$ \\
\hline Cryothecomonas armigera & $1.0 \times 10^{4}\left(1.1 \times 10^{4}\right)$ & $9.7 \times 10^{4}\left(2.0 \times 10^{4}\right)$ & $1.8 \times 10^{4}\left(1.6 \times 10^{4}\right)$ & $<50$ \\
\hline \multicolumn{5}{|l|}{ Heterotrophic dinoflagellates } \\
\hline Gymnodinium sp. & $<10$ & $<10$ & $<10$ & $<10$ \\
\hline Polykrikos sp. & $7(14)$ & $<10$ & $<10$ & $<10$ \\
\hline Gyrodiniun sp. & $<10$ & $<10$ & $<10$ & $14(28)$ \\
\hline Ciliates (total) & $93(106)$ & ND & $200(160)$ & $7(14)$ \\
\hline Oligotrichs & $93(106)$ & ND & $120(174)$ & $7(14)$ \\
\hline Mesodinium rubrum & $<10$ & ND & $80(69)$ & $<10$ \\
\hline
\end{tabular}

was a small colorless Gymnodinium sp. about $10 \times$ $17 \mu \mathrm{m}$ in size; it occurred in about $52 \%$ of the brine samples collected at the ice edge (Table 4). Its average density was between $10^{4}$ and $10^{5}$ cells $1^{-1}$ in ice edge

Table 3. Fine-scale spatial variability (mean cells $\mathrm{I}^{-1}$ with coefficient of variation, CV) in the brine assemblage at H90, 24 December 1991. Samples $\mathrm{A}, \mathrm{B}$ and $\mathrm{C}$ were obtained from $0.5 \mathrm{~m}$ deep holes drilled in the sea-ice at $1 \mathrm{~m}$ intervals along a $3 \mathrm{~m}$ transect. Three subsamples from each hole were enumerated in order to determine the within-sample variation (counting error). For Cryothecomonas spp., $75 \%$ of the total variation was due to differences among holes. For total ciliates, $91 \%$ of the total variation was due to differences among holes

\begin{tabular}{|c|c|c|c|c|c|}
\hline \multicolumn{6}{|c|}{ Cryothecomonas spp. } \\
\hline & \multicolumn{2}{|c|}{ Hole A } & \multicolumn{2}{|l|}{ Hole B } & Hole C \\
\hline Density & \multicolumn{2}{|c|}{$28.9 \times 10^{3}(16.3 \%)$} & \multicolumn{2}{|c|}{$25.1 \times 10^{3}(35.0 \%)$} & $0(0 \%)$ \\
\hline Source o & iation & $\mathrm{df}$ & MS & & $F$ \\
\hline Among $\mathrm{d}$ & ent holes & 2 & 739.8 & 10.2 & $16, p<0.05$ \\
\hline Within th & me hole & 6 & 72.4 & & \\
\hline \multicolumn{6}{|c|}{ Total ciliates } \\
\hline & \multicolumn{2}{|c|}{ Hole A } & \multicolumn{2}{|l|}{ Hole B } & Hole C \\
\hline Density & \multicolumn{2}{|c|}{$567(15.9 \%)$} & \multicolumn{2}{|l|}{$213(19.5 \%)$} & $36.7(68.6 \%)$ \\
\hline \multicolumn{2}{|c|}{ Source of variation } & df & MS & \multicolumn{2}{|r|}{$F$} \\
\hline \multirow{2}{*}{\multicolumn{2}{|c|}{$\begin{array}{l}\text { Among different holes } \\
\text { Within the same hole }\end{array}$}} & 2 & 218477.8 & \multirow{2}{*}{\multicolumn{2}{|c|}{$32.9916, p<0.001$}} \\
\hline & & 6 & 6622.2 & & \\
\hline
\end{tabular}

brine samples collected near the end of the sampling season (Table 1). On average, the Gymnodinium sp. contributed an estimated $64 \%$ of the total hetero. trophic dinoflagellate biomass.

Three $>20 \mu \mathrm{m}$ in size heterotrophic dinoflagellates were observed, Polykrikos sp., Gyrodinium sp. and a small Protoperidinium sp. (Tables $1 \& 2$ ). The Polykrikos sp. was over $100 \mu \mathrm{m}$ long (Fig. 2) and microscopic evidence indicates that it preys on the ca $10 \mu \mathrm{m}$ photosynthetic dinoflagellate that was the dominant alga in the brine (Stoecker et al. 1992). Polykrikos sp occurred in about $67 \%$ of the samples (Table 4), had average densities between

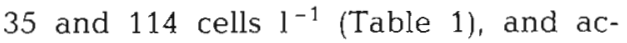
counted for an estimated $28 \%$ of the heterotrophic dinoflagellate biomass in brine samples collected near the ice edge. Gyrodinium sp. and Protoperidinum sp. occurred sporadically in the brine (Table 4 ).

The ciliate assemblage in the sea-ice brine was diverse; it included members of the orders Choreotrichida (e.g. tintinnids and Strobilidium), Oligotrichida (e.g. Strombidium and Laboea), Prorodontida (e.g. Spriroprorodon), Haptorida (e.g. Didinium, Lacrymaria, Mesodinium), Euplotida (e.g. Aspidisca, Euplotes), Scuticociliatida and other ciliates of unknown affinities. Except at $\mathrm{H} 90$, ciliate densities averaged between 1.0 and $5.0 \times 10^{3}$ cells $1^{-1}$ (Table 1 ) and cili- 
Table 4. Frequency of occurrence (no. of samples in which a species was present out of 3 samples taken at $1 \mathrm{~m}$ intervals) in the upper sea-ice brine, ice edge sites, McMurdo Sound, 1990-1991. Data only trom sites/dates from which $\geq 3$ samples were taken. If more than 3 samples were taken, 3 were randomly chosen for analyses here; thus not all species in Table 1 have a percent occurrence $>0$ in this table. Data are only presented for species with average densities $>10^{2}$ cells $1^{-1}$

\begin{tabular}{|c|c|c|c|c|c|c|c|c|}
\hline & \multicolumn{2}{|c|}{ Dec } & \multicolumn{4}{|c|}{ Jan } & & \multirow{2}{*}{$\begin{array}{c}\text { Percent of } \\
\text { samples present }\end{array}$} \\
\hline & 26 & & 5 & 7 & 10 & 21 & 23 & \\
\hline \multicolumn{9}{|l|}{ Heterotrophic flagellates } \\
\hline \multicolumn{9}{|l|}{ Cryothecomonas } \\
\hline C. armigera & 3 & 0 & 0 & 0 & 0 & 1 & 0 & $19 \%$ \\
\hline Cryothecomonas sp. & 0 & 0 & 0 & 0 & 0 & 0 & 0 & $0 \%$ \\
\hline \multicolumn{9}{|c|}{ Heterotrophic dinoflagellates } \\
\hline Gymnodinium sp. & 0 & 2 & 1 & 3 & 1 & 3 & 1 & $52 \%$ \\
\hline Polykrikos sp. & 1 & 1 & 3 & 3 & 2 & 2 & 2 & $67 \%$ \\
\hline Gyrodinium sp. & 0 & 0 & 0 & 2 & 0 & 0 & 0 & $10 \%$ \\
\hline Protoperidinium sp. & 0 & 0 & 0 & 1 & 0 & 0 & 0 & $5 \%$ \\
\hline \multicolumn{9}{|l|}{ Ciliates } \\
\hline Strombidium sp. 2 & 1 & 2 & 1 & 1 & 0 & 3 & 0 & $38 \%$ \\
\hline Strombidium sp. 3 & 1 & 0 & 0 & 1 & 2 & 1 & 0 & $24 \%$ \\
\hline Strombidium sp. 4 & 0 & 2 & 3 & 3 & 3 & 3 & 2 & $76 \%$ \\
\hline Strombidium sp. 6 & 0 & 0 & 0 & 0 & 0 & 0 & 1 & $5 \%$ \\
\hline Strombidium sp. 9 & 0 & 2 & 0 & 3 & 0 & 2 & 1 & $38 \%$ \\
\hline Strombidium sp. 14 & 0 & 1 & 1 & 2 & 1 & 3 & 1 & $43 \%$ \\
\hline Mesodinium rubrum & 1 & 3 & 3 & 3 & 3 & 3 & 3 & $90 \%$ \\
\hline Didinium $\mathrm{sp}$ & 0 & 0 & 2 & 1 & 0 & 0 & 3 & $28 \%$ \\
\hline Scuticociliate sp. & 1 & 3 & 0 & 0 & 0 & 0 & 0 & $19 \%$ \\
\hline
\end{tabular}

ual species densities of $\geq 100 \mathrm{l}^{-1}$ of brine (Table 1). The most common oligotrich was Strombidium sp. 4, a large cone-shaped species (ca $45 \times 60 \mu \mathrm{m}$ ) with a prominent sheath capping its posterior end; microscopic evidence indicated that this species primarily preyed on the $10 \mu \mathrm{m}$ photosynthetic dinoflagellate found in the brine (Stoecker et al. 1992). This Strombidium sp. occurred at average densities of ca $10^{3}$ cells $1^{-1}$ and in $76 \%$ of the samples taken near the ice edge (Tables $1 \& 4$ ). It accounted for about $45 \%$ of the total ciliate biomass (data not shown). Three plastidic Strombidium species, (spp. 2, 6 and 9) occurred at average combined densities of ca $10^{3} \mathrm{l}^{-1}$ of brine at the ice edge sites (Table 1; Stoecker et al. 1992).

A tintinnid, Laackmanniella sp. (oral diameter 25 to $35 \mu \mathrm{m}$, length 75 to $150 \mu \mathrm{m}$ ), only occurred in the 4 brine samples collected near the ice edge on 7 January. On this 1 date/location, it occurred at an average density of 226 (SD 197) $\mathrm{l}^{-1}$.

The ciliate which occurred most frequently in the brine was the autotrophic species Mesodinium rubrum (= Myrionecta rubra); it occurred in $90 \%$ of the samples collected near the ice edge

ates comprised on average $15 \%$ in late December and 48 to $85 \%$ in January of the heterotrophic protist biomass (Fig. 3).

The most common ciliates in the brine were oligotrichs; they comprised about $70 \%$ of the ciliate biomass (data not shown). Six Strombidium spp. dominated the oligotrich assemblage and occurred at average individ-

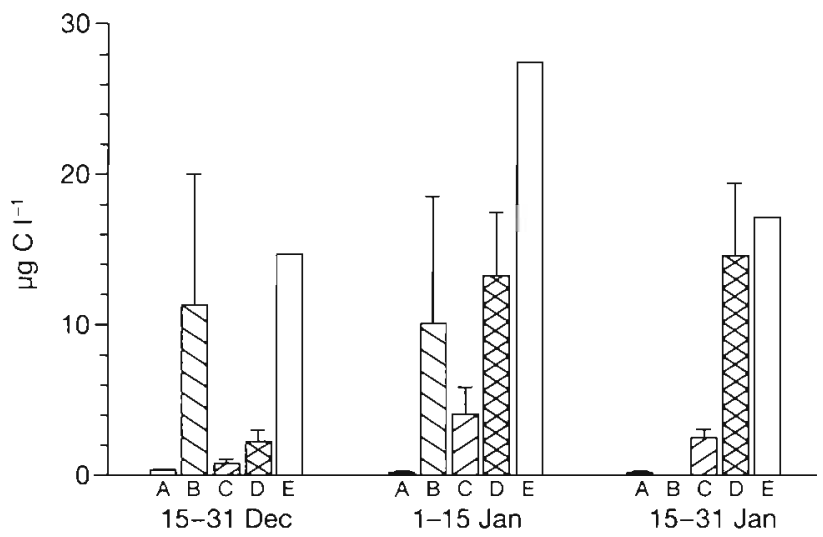

Fig. 3. Changes (+ SD) in the biomass of $(A) \leq 5 \mu \mathrm{m}$ heterotrophic flagellates, (B) Cryothecomonas spp., (C) heterotrophic dinoflagellates, (D) ciliates and (E) total protozoan biomass in the upper sea-ice brine at sites near the ice edge Average $M$. rubrum densities were 156 cells $l^{-1}$ in the

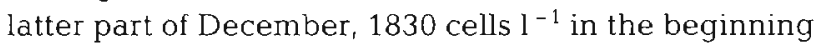
of January, and 728 cells $1^{-1}$ at the end of January in the brine samples collected near the ice edge (Table 1). On average, $M$. rubrum accounted for about $14 \%$ of the ciliate biomass (data not shown).

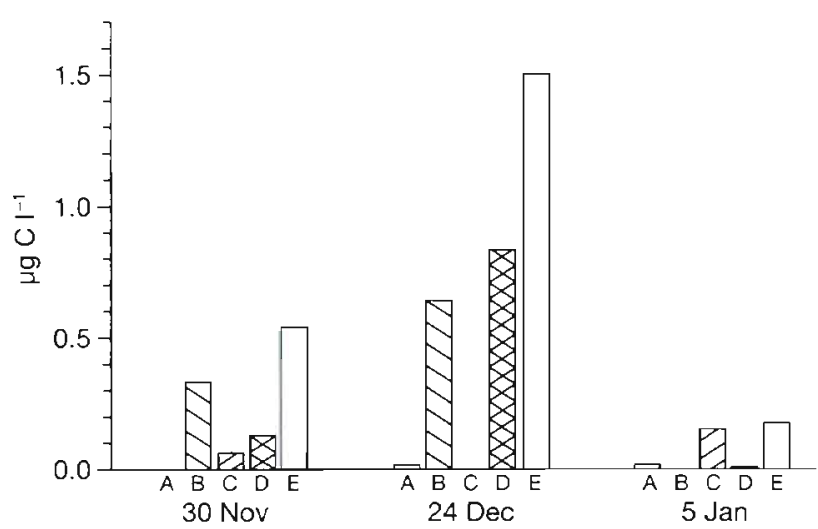

Fig. 4. Changes in the biomass of $(\mathrm{A}) \leq 5 \mu \mathrm{m}$ heterotrophic flagellates, (B) Cryothecomonas spp., (C) heterotrophic dinoflagellates, (D) ciliates and (E) total protozoan biomass in the upper sea-ice brine at $\mathrm{H} 90$
(Table 4) and was also observed at H90 (Table 2). 
The predatory ciliate Didinium spp. was not an important member of the assemblage until late in the season (Table 1). It occurred in $28 \%$ of the brine samples collected near the ice edge and had an average density of 740 cells $1^{-1}$ in late January (Tables 1 \& 4). Spiroprorodon, Aspidisca and Euplotes spp. did not appear in the brine until the latter half of January, providing a minor $(<10 \%)$ contribution to ciliate biomass (data not shown). However, it is likely that ciliates that are associated with surfaces, such as Aspidisca and Euplotes, were underestimated by our sampling technique.

An unidentified scuticociliate ca $10 \times 20$ to $25 \mu \mathrm{m}$ in size occurred in $19 \%$ of the samples collected near the ice edge and in the latter half of December occurred at average densities of 340 cells $\mathrm{l}^{-1}$ although it was rarer in January (Tables 1 \& 4). Scuticociliates are often associated with surfaces and may also have been underestimated by our sampling technique. The scuticociliates contributed $<1 \%$ of the total ciliate biomass in our samples (data not shown). Photosynthetic prey were not visible within this species.

\section{Horizontal spatial variability in the brine assemblage}

For all heterotrophic protists encountered in the brine, variation in density was high (Tables 1 \& 2). Among the $>5 \mu \mathrm{m}$ species that occurred at average densities $>10^{2}$ cells $l^{-1}$, most occurred in $<50 \%$ of the samples (Table 4). Variability due to counting technique could potentially cause this pattern. Thus, we compared variability among holes and among replicate counts using a random effects ANOVA. For 2 taxa analyzed in this fashion, we estimated that between 75 and $91 \%$ of the total variability in cell densities was due to differences among holes (Table 3). Differences among samples taken on the same date at the same site were primarily due to fine scale horizontal spatial variability rather than to counting errors. (Our sampling method did not permit analyses of vertical spatial variability).

Temporal patterns in the contribution of photosynthetic and non-photosynthetic protists to biomass

The contribution of heterotrophs to the protist biomass in the upper land-fast ice brine increased from ca $10 \%$ in December to an average of $57 \%$ during the latter half of January in the samples taken near the ice edge (Table 5). In the samples from H90, the heterotrophic component of the protistan biomass was $<10 \%$ and appeared to peak in late December (Table 5).
Table 5. Comparison of the average biomass $\left(\mu \mathrm{g} \mathrm{C}^{-1}\right)$ of photosynthetic and non-photosynthetic protists in the upper sea-ice brine, McMurdo Sound, 1990-91

\begin{tabular}{|c|c|c|c|}
\hline & $\begin{array}{l}\text { Photo- } \\
\text { synthetic }^{\text {a }}\end{array}$ & $\begin{array}{l}\text { Non- } \\
\text { photosynthetic }\end{array}$ & $\begin{array}{r}\text { Percent strictly } \\
\text { heterotrophic }\end{array}$ \\
\hline \multicolumn{4}{|l|}{ Ice edge sites } \\
\hline 15-31 Dec & 129.0 & 14.7 & $10.2 \%$ \\
\hline 1-15 Jan & 79.1 & 27.6 & $25.9 \%$ \\
\hline 15-31 Jan & 13.1 & 17.1 & $56.6 \%$ \\
\hline \multicolumn{4}{|l|}{ H9O } \\
\hline 30 Nov & 235.2 & 0.5 & $0.2 \%$ \\
\hline 24 Dec & 20.1 & 1.5 & $7.0 \%$ \\
\hline $5 \mathrm{Jan}$ & 34.5 & 0.2 & $0.5 \%$ \\
\hline \multicolumn{4}{|c|}{$\begin{array}{l}\text { a Data from Stoecker et al. (1992); includes photosynthetic } \\
\text { mixotrophic ciliates }\end{array}$} \\
\hline
\end{tabular}

\section{DISCUSSION}

The microalgal assemblage in the upper land-fast ice brine of McMurdo Sound shows many similarities to the surface-layer and internal ice assemblages reported from pack-ice (Stoecker et al. 1992). Likewise, the heterotrophic assemblage is composed of taxa reported from pack-ice (Bartsch 1989, reviewed in Garrison 1991). Cryothecomonas spp. can be a dominant component of the biomass in both the land-fast ice brine (Figs. 2 \& 3) and in pack-ice (Garrison \& Buck 1991, Thomsen et al. 1991). C. armigera in both pack and land-fast ice appears to prey primarily on Mantoniella sp. and other $<5 \mu \mathrm{m}$ flagellates.

Heterotrophic dinoflagellates are present in both land-fast ice brine and surface-layer pack-ice communities (Bartsch 1989, Garrison \& Buck 1989). However, we did not observe the large, spherical, athecate dinoflagellate that consumes diatoms and produces fecal pellets which has been observed in the surface slush layer of pack-ice (Buck et al. 1990). This difference may be due to the abundance of pennate diatoms in pack-ice and their scarcity in the land-fast ice brine (Garrison \& Buck 1989, Stoecker et al. 1992).

The ciliate taxa that we observed in the land-fast ice brine have been reported from pack-jce (Fenchel \& Lee 1972, Corliss \& Snyder 1986, Garrison \& Buck 1989). In both assemblages, ciliates can comprise a major fraction of the heterotrophic protist biomass, and oligotrichs (primarily Strombidium spp.) dominate the ciliate assemblage (Figs. $3 \& 4$, Tables 1 \& 2; reviewed in Garrison 1991). In both pack-ice and land-fast ice brine, the autotrophic ciliate Mesodinium rubrum (Myrionecta rubra) is one of the most frequently observed species (Tables 1, 2 \& 4; Garrison \& Buck 1989).

Some taxa reported from pack-ice were not observed in our samples from the upper sea-ice brine, these included choanoflagellates and foraminifera (reviewed 
in Garrison 1991). Foraminifera are known to be rare in congelation ice (Spindler et al. 1990) and land-fast ice is usually dominated by congelation ice (Garrison et al. 1986). The techniques used in the present study were not appropriate for counting amoeboa or for identifying various taxa of $<5 \mu \mathrm{m}$ heterotrophic flagellates. Thus, many of the $<5 \mu \mathrm{m}$ species reported from landfast ice in East Antarctica (Takahashi 1987) or from pack-ice (reviewed in Garrison 1991) may have been present but unreported in our samples as specific taxa. It is interesting to note that although micrometazoa are found in pack-ice and land-fast ice bottom type microbial communities (reviewed in Garrison 1991), we did not observe them in the upper land-fast ice brine. The grazers and predators in the upper land-fast ice brine were all protists.

Most of the heterotrophic flagellates and ciliates observed in pack-ice or land-fast ice are also found in the plankton (Garrison 1991, Thomsen et al. 1991). Internal communities in pack-ice are thought to be initiated from cells or cysts harvested from the water column by frazil ice or entrapped when the ice is formed (reviewed in Garrison 1991). It is likely that many of the species found in land-fast ice arrive in the same manner. However, it seems possible that some of larger protists found in the brine pockets, especially those only observed in the late austral spring or summer, may invade the ice from the water column.

It is interesting that many of the larger species most frequently found in the brine tend to swim toward light or upward. Mesodinium rubrum and Strombidium spp. can swim at speeds of up to $1 \mathrm{~m} \mathrm{~h}^{-1}$ or more (Crawford 1989, Jonsson 1989). Swimming speeds for heterotrophic dinoflagellates have not been reported, but photosynthetic ones have maximum swimming speeds of up to $1 \mathrm{~m} \mathrm{~h}^{-1}$ (Taylor \& Pollingher 1987). Relatively long, straight brine channels are found in columnar sea-ice and in the late austral spring, when brine drainage occurs, the ice becomes extremely porous and $\mathrm{mm}$ to $\mathrm{cm}$ wide channels may be present at times (Maykut 1985, Eicken 1992, Weissenberger et al 1992). Cysts of brine microaglae are found in the water column when brine drainage occurs (Stoecker et al. 1992. Stoecker unpubl. data) and therefore it seems possible that planktonic organisms may invade the ice at the same time.

A conspicuous feature of the heterotrophic protist assemblage is its fine-scale (order of meters) spatial variability in composition (Tables $3 \& 4$ ). We believe that this fine-textured spatial heterogeneity is due to the structure of land-fast sea-ice. In McMurdo Sound, the upper $1 \mathrm{~m}$ of ice cores is dominated by congelation (columnar) ice (Jeffries \& Weeks 1991). In congelation sea-ice, brine channnels are orientated vertically and are long and straight (Maykut 1985, Weissenberger et al. 1992). Particularly during early and mid-spring, when brine volumes in the upper ice in McMurdo sound are low (Buckley \& Trodahl 1990), this vertical structure should limit horizontal dispersion of protists in the ice. When brine channels open to the underlying water column, the columnar structure should favor vertical migration of motile protists (such as planktonic ciliates and dinoflagellates) into the ice, where they may colonize brine pockets, but the columnar structure may still inhibit horizontal dispersion of the colonists.

Investigations of pack-ice microbial communities have suggested a successional sequence, with the heterotrophic components increasing in the spring and summer (Garrison \& Buck 1989). As in the pack-ice (reviewed in Garrison 1991), land-fast ice protist populations are highly variable, but general successional trends are evident (Tables $1 \& 2$, Figs. $3 \& 4$ ). Average microalgal biomass $1^{-1}$ of brine tends to decrease as heterotrophic protist biomass increases during the spring and early summer (Table 5). At H90, succession was truncated because of early decay of the ice. By 5 January at this site, the brine salinity was $\leq 2$ psu and the upper ice was extremely porous (Table 2; Stoecker et al. 1992). Just before the ice decays (late January \& February at most sites in McMurdo Sound), both protozoan and microalgal populations decrease (Table 5). At the ice edge sites, the average percent contribution of heterotrophs to the total protist biomass increased from ca $10 \%$ in late December to over $50 \%$ by the end of January (Table 5).

Changes in microalgal biomass $1^{-1}$ of brine are partly due to dilution of the populations as brine volume increases, losses due to brine drainage and possibly due to death due to salinity changes, and encystment of the dominant species (Stoecker et al. 1992), but grazing is probably also important. The dominant phagotrophs, Cryothecomonas spp., the heterotrophic dinoflagellates and Strombidium spp., are all consumers of microalgae and other small eucaryotic cells.

The changes in heterotrophic protist biomass are probably due to a combination of growth of in situ populations, migration from the water column, dilution due to increases in brine volume and losses due to brine drainage, possibly death due to salinity changes, and predation. Some of the protists in the brine are predators on other heterotrophic protists. The small gymnodinioid dinoflagellate did not appear to contain. plastidic food, it is likely that this species was a predator on Cryothecomonas spp. and other heterotrophic flagellates. At the ice edge, Didinium spp., which are usually voracious predators on other ciliates, were an important component of the brine during the end of January (Table 1). 
Sea-ice, particularly multi-year and pack-ice, is notoriously heterogenous in its structure, nutrient content and in the distribution and abundance of microbial communities (reviewed in Garrison 1991). We hypothesize that the activities of phagotrophic protists are at least partly responsible for the observed heterogeneity in older sea-ice. The large, but variable, contribution of heterotrophs to land-fast ice brine protist assemblages just prior to ice decay and break-out suggests that grazing directly influences the distribution and abundance of bacteria and microalgae in ice floes that are formed from land-fast ice. Phagotrophic protists are thought to be the major contributors to nutrient regeneration in planktonic environments (Caron 1991), and it is likely that they play similar roles in brine communities. In pack-ice floes $>2$ mo in age, nitrate is often depleted and ammonia levels are often elevated (Garrison et al. 1990, Dieckmann et al. 1991). Levels and ratios of inorganic nutrients, as well as the composition of existing assemblages, must have an important influence on the development and species composition of ice microalgal communities in multiyear ice.

In Antarctica, pack-ice is more extensive than landfast ice, but logistical problems make it difficult to document or experimentally investigate seasonal changes in the microbial communities of pack-ice. However, evidence strongly suggests that the activities of microorganisms (bacteria, microalgae and heterotrophic protists) influence ice decay and break-up (reviewed in Eicken et al. 1991) as well as being important in primary production in polar waters (reviewed in Legendre et al. 1992). Percent ice cover has an important influence on the structure and function of polar ecosystems as well as being an important parameter in global energy balance and atmosphereocean interactions (reviewed in Eicken 1992). Investigations of the microbial communities of sea-ice, and their interactions with their physical environment and the underlying water column, are necessary in order to understand polar ecosystem dynamics. The existence of upper sea-ice brine communities in land-fast ice, which is more accessible than pack-ice, should facilitate time-series studies and experimental investigations of the interactions between sea-ice microbial communities and their environment.

Acknowledgements. The authors thank Ms Jessie Alstatt, Ms Gerri Miceli, Ms Tiffany Moisan and Mr Erik Zettler for field assistance, sample analysis and good comeraderie, Ms L. H. Davis for laboratory assistance, the helicopter pilots and crews of U.S Navy VXE-6 Squadron and the U.S. Coast Guard's 'Polar Sea' Aviation detachment, the staff of the Berg Field Center and the Eklund Biological Laboratory for excellent support. This work was supported by NSF grant DPPO-8816668 to M.P. and D.K.S.

\section{LITERATURE CITED}

Ackley, S. F., Buck, K. R., Taguchi, S. (1979). Standing crop of algae in the sea ice of the Weddell Sea region. Deep Sea Res. 26A: 269-281

Arrigo, K., Dieckmann, G., Gosselin, M., Sullivan, C. (1990). Studies on the nutrient status in sea ice and underlying platelet layer of McMurdo Sound. Antarctic J. U.S. 25: $185-188$

Arrigo, K. R., Sullivan, C. W., Kremer, J. N. (1991). A biooptical model of Antarctic sea ice. J. geophys. Res. 96: $10581-10592$

Bartsch, A. (1989) Die Eisalgenflora des Weddellmeeres (Antarktis): Artenzusammensetzung und Biomasse sowie ökophysiologie ausgewählter Arten. Ber. Polarforsch. 63: $1-110$

Bianchi, F., Boldrin A., Cioce, F., Dieckmann, G., Kuosa, H., Larsson, A.-M., Nothig, E.-M., Sehlstedt, P.-I., Socal, G., Syvertsen, E. E. (1992). Phytoplankton distribution in relation to sea ice, hydrography and nutrients in the northwestern Weddell Sea in early spring 1988 during EPOS. Polar Biol. 12: 225-235

Buck, K. R., Bolt, P., Garrison, D. L. (1990). Phagotrophy and fecal pellet production by an athecate dinoflagellate in Antarctic sea ice. Mar. Ecol. Prog. Ser. 60: 75-84

Buckley, R. G., Trodahl, H. J. (1990). Scattering and absorption of light by sea ice. In: Ackley, S. F., Weeks, W. F. (eds.) Sea ice properties and processes. CRREL Monograph 90-1, U.S. Army Corps of Engineers Cold Regions Research \& Engineering Laboratory, Hanover, $\mathrm{NH}_{1}$ p. $49-52$

Buynitskiy, V. K. (1968). The influence of microalgae on the structure and strength of Antarctic sea ice. Oceanology 8: $771-776$

Capriulo, G. M., Sherr, E. B., Sherr, B. F. (1991). Trophic behavior and related community feeding activities of heterotrophic marine protists. In: Reid, P. C., Turley, C. M., Burkill, P. H. (eds.) Protozoa and their role in marine processes. Springer-Verlag, Berlin, p. 219-265

Caron, D. A. (1991). Evolving role of protozoa in aquatic nutrient cycles. In: Reid, P. C., Turley, C. M, Burkill, P. H. (eds.) Protozoa and their role in marine processes. Springer-Verlag, Berlin, p. 387-415

Comiso, J. C. (1986). Characteristics of Arctic Winter sea ice from satellite multispectral microwave observations. J. geophys. Res. 91: 975-994

Corliss, J. O., Snyder, R. A. (1986). Preliminary description of several new ciliates from the Antarctica, including Cohnilembus grassei n. sp. Protistologica 22: 39-46

Crawford, D. W. (1989). Mesodinium rubrum: the phytoplankter that wasn't. Mar. Ecol. Prog. Ser. 58: 161-174

Dieckmann, G. S., Lange, M. A., Ackley, S. F., Jennings, J. C. Jr (1991). The nutrient status in sea ice of the Weddell Sea during winter: effects of sea ice texture and algae. Polar Biol. 11: 449-456

Eicken, H. (1992). The role of sea ice in structuring Antarctic ecosystems. Polar Biol. 12: 3-13

Eicken, H., Ackley, S. F., Richter-Menge, J. A., Lange, M. A. (1991). Is the strength of sea ice related to its chlorophyll content? Polar Biol. 11: $347-350$

Fenchel, T., Lee, C. C. (1972). Studies on ciliates associated with sea ice from Antarctica. Arch. Protiestenk. 114: $231-236$

Garrison, D. L. (1991). Antarctic sea ice biota. Am. Zool. 31. $17-33$

Garison, D. L., Buck, K. R. (1989). The biota of Antarctic pack ice in the Weddell Sea and Antarctica pensinsula regions. Polar Biol. 10: 211-219 
Garrison, D. L., Buck, K. R. (1991). Surface-layer sea ice assemblages in Antarctic pack ice during the austral spring: environmental conditions, primary production and community structure. Mar. Ecol. Prog. Ser. 75: 161-172

Garrison, D. L., Close, A. R., Gordon, L. 1. (1990). Nutrient concentrations in Antarctic pack ice during winter. In: Ackley, S. F., Weeks, W. F. (eds.) Sea ice properties and processes. CRREL Monograph 90-1 U.S. Army Corps of Engineers Cold Regions Research \& Engineering Laboratory, Hanover, NH, p. 35-40

Garrison, D. L., Sullivan, C. W., Ackley, S. F. (1986). Sea ice microbial communities in Antarctica. BioSci. 36: 243-250

Haas, L. W. (1982). Improved epifluorescence microscopy for observing planktonic organisms. Annls Inst. océanogr., Paris 58(S): 261-266

Horner, R., Ackley, S. F., Dieckmann, G. S., Gulliksen, B., Hoshiai, T., Legendre, L., Melnikov, I. A., Reeburgh, W. S., Spindler, M., Sullivan, C. W. (1992). Ecology of sea ice biota. 1. Habitat, terminology, and methodology. Polar Biol. 12: $417-427$

Hoshiai, T. (1972). Diatom distribution in sea ice neas McMurdo station and Syowa Stations. Antarctic J. U.S. 7: $84-85$

Jeffries, M. O., Weeks, W. F. (1991). Fast-ice properties and structure in McMurdo Sound. Antarctic J. U.S. 26: 94-95

Jonsson, P. R. (1989). Vertical distribution of planktonic ciliates - an experimental analysis of swimming behaviour. Mar. Ecol. Prog. Ser. 52: 39-53

Knox, G. A. (1990). Primary production and consumption in McMurdo Sound, Antarctica. In: Kerry, K. R., Hempel, G. (eds.) Antarctic ecosystems: ecological change and conservation. Springer-Verlag, Berlin, p. 115-128

Kottmeier, S. T., Sullivan, C. W. (1988). Sea ice microbial communities (SIMCO). 9. Effects of temperature and salinity on rates of metabolism and growth of autotrophs and heterotrophs. Polar Biol. 8: 293-304

Legendre, L., Ackley, S. F., Dieckmann, G. S., Gulliksen, B., Horner, R., Hoshiai, T., Melnikov, I. A., Reeburgh, W. S., Splindler, M., Sullivan, C. W. (1992). Ecology of sea ice biota. 2. Global significance. Polar Biol. 12: 429-444

Lessard, E. (1991). The trophic role of heterotrophic dinoflagellates in diverse marine environments. Mar microb. Fd Webs 5: 49-58

Lizotte, M. P., Sullivan, C. W. (1992). Photosynthetic capacity in microalgae associated with Antarctic pack ice. Polar Biol. 12: $497-502$

Matsuda, O., Ishikawa, S., Kawauchi, K. (1990). Seasonal variation of particulate orgnaic matter under the Antarctic fast ice and its importance to benthic life. In: Kerry, K. R., Hempel, G. (eds.) Antarctic ecosystems: ecological change and conservation. Springer-Verlag, Berlin, p. 143-148

Maykut, G. A. (1985). The ice environment. In: Horner, R. A., (ed.) Sea ice biota. CRC Press Inc., Boca Raton, p. 21-82

McConville, M. J., Wetherbee, R. (1983). The bottom-ice microalgal community from annual ice in the inshore waters of east Antarctica. J. Phycol. 19: 431-439

Meguro, H. (1962). Plankton ice in the Antarctic ocean. Nankyokyu Shiryo 14: 72-79

This article was submitted to the editor
Meyers, R. H., Milton, J. S. (1991). A first course in the theory of linear statistical models. PWS-Kent Publ. Co., Boston

Palmisano, A. C., Sullivan, C. W. (1983). Sea Ice Microbial Communities (SIMCO) I. Distribution, abundance, and primary production of ice microalgae in McMurdo Sound, Antarctica in 1980. Polar Biol. 2: 171-177

Parsons, T R., Maita, Y., Lalli, C. M. (1984). A manual of chemical and biological methods for seawater analysis. Pergamon Press, Oxford

Putt, M., Stoecker, D. K. (1989). An experimentally determined carbon:volume ratio for marine 'oligotrichous' ciliates from estuarine and coastal waters. Limnol. Oceanogr. 34: $1097-1103$

Sasaki, H., Watanabe, K. (1984). Underwater observations of ice algae in Lutzow-Holm Bay, Antarctica. Antarctic Record 81: 1-8

SooHoo, J. B., Palmisano, A. C., Kottmeier, S. T., Lizotte, M. P., SooHoo, S. L., Sullivan, C. W. (1987). Spectral light absorption and quantum yield of photosynthesis in sea ice microalgae and a bloom of Phaeocytis pouchetti from McMurdo Sound, Antarctica. Mar. Ecol. Prog. Ser. 39: $175-189$

Spindler, M., Dieckmann, G. S., Lange, M. A. (1990). Seasonal and geographic variations in sea ice community structure of the Weddell Sea, Antarctica. In: Kerry, K. R., Hempel, G. (eds.) Antarctic ecosystems, ecological change and conservation. Springer-Verlag, Berlin, p. 129-135

Stoecker, D. K., Buck, K. R., Putt, M. (1990). A flagellate and ciliate dominated microbial community in the land-fast ice. Antarctic J. U.S. 25: 197-199

Stoecker, D. K., Buck, K. R, Putt, M. (1991). Photosynthetic dinoflagellates and their cysts characteristic of the landfast ice. Antarctic J. U.S. 26: 143-144

Stoecker, D. K., Buck, K. R., Putt, M. (1992). Changes in the sea-ice brine community during the spring-summer transition, McMurdo Sound, Antarctica. 1. Photosynthetic protists. Mar. Ecol. Prog. Ser. 84: 265-278

Takahashi, E. (1987). Loricate and scale-bearing protists from Lutzow-Holm Bay, Antarctica II. Four marine species of Paraphysomonas (Chrysophyceae) including two new species from the fast-ice covered coastal area. Jap. J. Phycol 35: 155-166

Taylor, F. J. R., Pollingher, U. (1987). Ecology of dinoflagellates. In: Taylor, F. J. R. (ed.) The biology of dinoflagellates. Blackwell Scientific Publications, Oxford, p. 398-523

Thomsen, H. A., Buck, K. R., Bolt, P. A., Garrison, D. L. (1991). Fine structure and biology of Cryothecomonas gen. nov. (Protista incertae sedis) from the ice biota. Can. J. Zool. 69: $1048-1070$

Weissenberger, J., Dieckmann, G., Gradinger, R., Spindler, M. (1992). Sea ice: a cast technique to examine and analyze brine pockets and channel structure. Limnol. Oceanogr. 37: 179-183

Zwally, H. J., Parkinson, C. L., Comiso, J. C. (1983). Variability of Antarctic sea ice and changes in carbon dioxide. Science 220: 1005-1012

Manuscript first received: September 22, 1992 Revised version accepted: February 9, 1993 